\title{
PENDEKATAN FILSAFAT ILMU DALAM UJI KONSTITUSIONALITAS TEMBAK MATI SEBAGAI EKSEKUSI PIDANA MATI (TELAAH PUTUSAN MAHKAMAH KONSITUSI NO. 21/PUU-VI/2008)
}

\author{
Muhammad Kadafi \\ Universitas Malahayati \\ J1. Pramuka No. 27 Kemiling Bandar Lampung \\ Email:kdv_bintang@yahoo.com.
}

\begin{abstract}
The holistic Legal studies works not only focusing on rule but also focusing on behavior. The legal studies which isolates the work from other disciplines can cause incomplete understanding. The constitutionality assessment of dead shoot as a dead sentence on constitutional verdict number 21/PUU-VI/2008 should meet petitioner's argumentation and basic consideration. In this case, the petitioner proposes a witness together with experts from several expertise consist of religious men/women, anesthesiologists, orthopedic surgeon, Islamic judges and criminologist. Besides, the executives deliver the argumentation and statements in which those statements will be basis of making decision by court of law.
\end{abstract}

Keywords: Philosophy; Constitutionality of Dead Shoot.

\begin{abstract}
Abstrak
Ilmu hukum yang holistik tidak bisa bekerja sendiri dengan memfokuskan pada peraturan (rule) melainkan juga pada perilaku. Ilmu hukum yang mengisolasikan diri dari keterkaitannya dengan disiplin ilmu lain akan memiliki penjelasan yang sangat kurang. Jika di hubungkan dengan argumentasi Pemohon dan dasar pertimbangan dalam Putusan MK No. 21/PUU-VI/2008 terkait uji konstitusionalitas tembak mati sebagai eksekusi pidana mati setidaknya terpenuhi. Dalam hal ini Pemohon mengajukan Saksi beserta berbagai ahli berdasarkan pengalaman dan keahliannya masing-masing. Ada Rohaniawan, Ahli Anastesi, Ahli Bedah Orthopedi, Ahli Hukum Islam, dan Ahli Hukum Pidana. Tidak ketinggalan pula dari pihak Pemerintah juga memberikan keterangan dalam persidangan. Dimana keterangan-keterangan tersebut sebagian digunakan sebagai dasar pertimbangan untuk mengambil keputusan oleh Mahkamah.
\end{abstract}

Kata Kunci: Filsafat Ilmu; Konstitusionalitas Pidana Tembak Mati.

\section{A. Pendahuluan}

FX. Adji Semekto dalam tulisannya "Menggugat Relasi Filsafat Posistivisme Dengan Ajaran Hukum Doktrinal" memberikan tiga simpulan. Pertama, kajian hukum doktrinal memiliki tradisi pemikiran yang bersumber dari filsafat masa Yunani yang kemudian dikembangkan pada era tumbuhnya ajaran hukum alam di Eropa Barat. Tradisi pemikirannya bersumber dari ajaran-ajaran agama dan olah pikir manusia dengan rasionalitasnya. Dalam batas-batas ini, pemahaman nilai atau ajaran sebenarnya sangat penting bagi pengkajian hukum doktrinal. Inilah ciri khas dari hukum doktrinal, bahwa keberadaannya tidak mendasarkan pada logiko-empirik sebagaimana dikembangkan filsafat Positivisme, akan tetapi pada cara berpikir $a$ priori. Cara berpikir a priori tidak menggantungkan pada fakta sosial (empirik) tetap mengandalkan kekuatan nilai-nilai dan ajaran-ajaran . Perwujudannya yang sangat khas adalah:

1. FX. Adji Samekto, "Menggugat Relasi Filsafat Posistivisme Dengan Ajaran Hukum Doktrinal”, Jurnal Dinamika Hukum, Vol. 12, No. 1, Januari 2012, hlm. 83. 
fiksi hukum. Ajaran ini dikembangkan jauh sebelum ilmu hukum dikembangkan dalam cara berpikir filsafat positivisme. Apabila ajaran hukum doktrinal itu dikaji dalam perspektif filsafat positivisme, maka menjadi bertentangan karena filsafat positivisme mengandalkan verifikasi melalui pembuktian empiris.

Kedua, ilmu hukum yang dikembangkan dengan cara berpikir filsafat positivisme menyebabkan pengkajian ilmu hukum seperti pengkajian pada ilmu-ilmu lain yang dikembangkan dalam filsafat positivisme berciri logiko-empirik, objektif, reduksionis, deterministik dan bebas nilai. Ciri bermanfaat untuk mengembangkan ilmu menjadi bersifat ilmiah. Oleh karena itu untuk mengilmiahkan ilmu hukum, maka kajian ilmu hukum harus dibebaskan dari unsur-unsur yang bersifat tidak konkrit, tidak rasional seperti moral, kebaikan dan ajaran-ajaran tentang kebaikan lainnya. Ilmu hukum harus didudukkan seperti ilmuilmu dalam kerabat sains; netral dan bebas nilai.

Ketiga, ilmu hukum yang dikembangkan dalam tradisi pemikiran positivisme dalam beberapa hal bertentangan dengan tradisi pemikiran hukum doktrinal yang tumbuh pada masa pra-positivisme. Pengkajian hukum dalam tradisi filsafat positivisme, tidak serta merta identik dengan tradisi pemikiran hukum doktrinal. Beberapa prinsip di dalam positivisme bahkan bertentangan di dalam ilmu hukum doktrinal seperti ditunjukkan dengan adanya ajaran fiksi hukum maupun kepastian hukum.

Berdasarkan ketiga simpulan tersebut akhirnya Samekto memberikan saran kepada para pengkaji ilmu hukum doktrinal (normatif) untuk tidak sekedar mengupas aturan hukum positif saja. Mengeksplorasi nilai filsafat dibalik terbitnya suatu aturan menjadi tidak terelakkan dalam kajian hukum doktrinal. Diharapkan para pembaca menyadari kembali bahwa ilmu hukum doktrinal sesungguhnya tidaklah mudah. Ia tidak sekedar mengupas aturan-aturan hukum positif saja, tetapi menukik lebih dalam untuk menjelajah nilai-nilai dan ajaran-ajaran yang menyebabkan kenapa suatu aturan hukum tertentu harus diberlakukan. $^{2}$

Lebih lanjut Samekto mengatakan hukum sangat sulit untuk dilepaskan dari basis sosialnya. Oleh karena itu tidak dapat dicegah terjadinya interaksi antar disiplin dan proses saling memasuki. Inilah yang menjadi landasan penyebutan ilmu hukum yang holistik. Ilmu hukum yang holistik tidak bisa bekerja sendiri dengan memfokuskan pada peraturan (rule) melainkan juga pada perilaku. Dalam ilmu hukum holistik, hukum adalah untuk manusia, dan dari situ akan mengalir pendekatan, fokus studi, metodologi dan sebagainya. Ilmu hukum yang mengisolasikan diri dari keterkaitannya dengan disiplin ilmu lain akan memiliki penjelasan yang sangat kurang.

Berdasarkan uraian tersebut di atas, maka dapat diringkas, Semekto memberikan saran kepada para pengkaji ilmu hukum doktrinal (normatif) untuk tidak sekedar mengupas aturan hukum positif saja. Lebih lanjut Semekto juga berpendapat bahwa ilmu hukum yang mengisolasikan diri dari keterkaitannya dengan disiplin ilmu lain akan memiliki penjelasan yang sangat kurang. ${ }^{3}$

Ilmu hukum kedudukannya tidak hanya sekedar berbicara tentang rasa inferioritas saja, tetapi memiliki juga tujuan mengungkapkan dan menganalisis landasan kefilsafatannya untuk memperoleh pandangan yang jernih tentang ilmu hukum dan perspektif filsafat ilmu, khususnya aspek epistemologi yang memberikan penjelasan terhadap hakikat ilmu hukum sebagai ilmu. Epistemologi merupakan salah-satu dari landasan pendekatan filsafat ilmu, pendekatan epistemologi pada intinya mengulas bagaimana caranya mendapatkan ilmu pengetahuan. ${ }^{5}$ Untuk meng-sinkronkan pendapat Semekto dan menjelaskan hakikat

2. Ibid, hlm. 83-84.

3. Ibid.

4. Eny Suastuti, 2007, Pendekatan Filsafat Ilmu Dalam Ilmu Hukum, Bunga Rampai Hakikat Keilmuwan Ilmu Hukum: Suatu Tinjauan dari Susut Pandang Filsafat Ilmu, Ed. Trianto \& Titik Triwulan Tutik, Jakarta, Prestasi

5. Pujun S. Suriasumantri, 2007, Filsafat Ilmu: Sebuah Pengantar Populer, Jakarta, Pustaka Sinar Harapan, hlm. 35. 
ilmu hukum sebagai ilmu melalui pendekatan salah satu landasan filsafat ilmu (epistemologi) maka dilakukan telaah terhadap Putusan Mahkamah Konsitusi No. $21 /$ PUU-VI/2008 mengenai “Uji Konstitusionalitas Tembak Mati Sebagai Eksekusi Pidana Mati”.

Berangkat dari latar belakang yang telah diuraikan di bagian pendahuluan, maka dapat dirumuskan dua permasalahan, yaitu sebagai berikut: (1) Argumen apa yang digunakan Pemohon dalam " $\mathrm{Uji}$ Konstitusionalitas Tembak Mati Sebagai Eksekusi Pidana Mati"? (2) Apakah benar pendekatan filsafat ilmu melalui landasan epistemologi telah digunakan dalam Putusan Mahkamah Konsitusi No. 21/PUU-VI/2008 mengenai "Uji Konstitusionalitas Tembak Mati Sebagai Eksekusi Pidana Mati”?

\section{B. Pembahasan}

\section{Filsafat Ilmu}

Aristotales beranggapan, bahwa kewajiban filsafat adalah menyelidiki sebab dan asas segala benda. Dengan demikian filsafat bersifat ilmu yang umum sekali. Tugas penyelidikan tentang sebab telah dibagi sekarang oleh filsafat dengan ilmu. Sebab awalatau sebab dari sebabmasuk bidang filsafat. Sedang pertanyaan "apa sebab kejadian?" masuk medan ilmu. Jadi tentang asas dan sebab yang pertanda masuk medan filsafat. ${ }^{6}$

Filsafat ilmu merupakan telaah kefilsafatan yang ingin menjawab beberapa pertanyaan mengenai hakikat ilmu seperti: ${ }^{7}$

a. Obyek apa yang ditelaah ilmu ? Bagaimana ujud yang hakiki dari obyek tersebut? Bagaimana hubungan antara obyek tadi dengan daya tangkap manusia yang membuahkan pengetahuan? (Landasan ontologis)

b. Bagaimana proses yang memungkinkan ditimbanya pengetahuan yang berupa ilmu? Bagaimana prosedurnya? Hal-hal apa yang harus diperhatikan agar mendakan pengetahuan yang benar? Apakah kriterianya? Apa yang disebut kebenaran itu? Adakah kriterianya?
Cara/teknik/sarana apa yang membantu kita dalam mendapatkan pengetahuan yang berupa ilmu? (Landasan epistemologis)

c. Untuk apa pengetahuan yang berupa ilmu itu dipergunakan? Bagaimana kaitan antara cara penggunaan tersebut dengan kaidah-kaidah moral? Bagaimana penentuan obyek yang ditelaah berdasarkan pilihan-pilihan moral? Bagaimana kaitan antara teknik prosedural yang merupakan operasionalisasi metode ilmiah dengan norma-norma moral/profesional? (Landasan aksiologis)

\section{Kewenangan dan Kewajiban Mahkamah Konstitusi}

Kehadiran MK dalam sistem ketatanegaraan tidak lain berperan sebagai pengawal konstitusi (the guardian of the constitution), agar konstitusi selalu dijadikan landasan dan dijalankan secara konsisten oleh setiap komponen negara dan masyarakat. MK ditaati dan dilaksanakan secara konsisten, serta mendorong dan mengarahkan proses demokratisasi berdasarkan konstitusi. Selain itu, MK berperan sebagai penafsir tunggal dan tertinggi atas UUD, yang direfleksikan melalui putusan-putusan sesuai kewenangannya. Dengan adanya $\mathrm{MK}$, proses penjaminan demokrasi yang konstitusional diharapkan dapat diwujudkan melalui proses penjabaran dari empat kewenangan konstitusional (constitutionally entrusted powers) dan satu kewajiban konstitusional (constitutional obligation). ${ }^{8}$

Pasal 24C ayat (1) dan (2) UndangUndang Dasar Negara Republik Indonesia Tahun 1945 menggariskan wewenang Mahkamah Konstitusi adalah sebagai berikut:

(1) Mahkamah Konstitusi berwenang mengadili pada tingkat pertama dan terakhir yang putusannya bersifat final untuk menguji undang-undang terhadap Undang-Undang Dasar, memutus sengketa kewenangan lembaga negara yang kewenangannya diberikan oleh Undang-Undang Dasar, memutus

6.Sidi Gazalba, 1992, Sistematika Filsafat: Buku Pertama: Pengantar Kepada Dunia Filsafat, Jakarta, PT Bulan Bintang, hlm. 17.

7.Jujun S. Suriasumantri, Op. cit, hlm. 33 dan hlm 35.

8.Mahkamah Konstitusi, 2004, Cetak Biru Membangun Mahkamah Konstitusi, Jakarta, Mahkamah Konstitusi Republik Indonesia, hlm. 45-46. 
pembubaran partai politik, dan memutus perselisihan tentang hasil pemilu.

(2) Mahkamah Konstitusi wajib memberi putusan atas pendapat Dewan Perwakilan Rakyat mengenai dugaan pelanggaran Presiden dan/atau Wakil Presiden menurut Undang-Undang Dasar.

Secara khusus, wewenang Mahkamah Konstitusi tersebut diatur lagi dalam Pasal 10 Undang-Undang No. 24 Tahun 2003 tentang Mahkamah Konstitusi dengan merinci sebagai berikut:

a. Menguji undang-undang terhadap Undang-Undang Dasar Negara Republik Indonesia tahun 1945;

b. Memutus sengketa kewenangan lembaga negara yang kewenangannya diberikan oleh Undang-Undang Dasar Negara Republik Indonesia tahun 1945;

c. Memutus pembubaran partai politik; dan

d. Memutus perselisihan tentang hasil pemilihan umum;

e. Mahkamah Konstitusi wajib memberi putusan atas pendapat DPR bahwa Presiden dan/atau Wakil Presiden diduga telah melakukan pelanggaran hukum berupa pengkhianatan terhadap negara, korupsi, penyuapan, tindak pidana berat lainnya, atau perbuatan tercela, dan/atau Wakil Presiden sebagaimana dimaksud dalam UndangUndang Dasar Negara Republik Indonesia tahun 1945.

Pada hakikatnya, fungsi utama MK adalah mengawal supaya konstitusi dijalankan dengan konsisten (the guardian of constitution) dan menafsirkan konstitusi atau UUD (the interpreter of constitution). Dengan fungsi dan wewenang tersebut, keberadaan MK memiliki arti penting dan peranan strategis dalam perkembangan ketatanegaraan dewasa ini karena segala ketentuan atau kebijakan yang dibuat penyelenggara negara dapat diukur dalam hal konstitusional atau tidak oleh MK. Dengan demikian, setiap penyelenggaraan pemerintah selalu terbangun oleh dan berlandaskan pada prinsip-prinsip dan ketentuan konstitusi. ${ }^{9}$

\section{Pendekatan Filsafat Ilmu dalam Uji Konstitusionalitas Tembak Mati Sebagai Eksekusi Pidana Mati}

a. Kedudukan Hukum (Legal Standing) dan Argumentasi Konstitusional Pemohon

Pemohon dalam Perkara No. 21/PUUVI/2008 mengenai "Uji Konstitusionalitas Tembak Mati Sebagai Eksekusi Pidana Mati" adalah Amrozi bin Nurhasyim, Ali Ghufron bin Nurhasyim als. Muklas, dan Abdul Azis als. Imam Samudra (Amrozi dkk) yang diwakili oleh kuasa hukumnya, A. Wirawan Adnan dkk., yang berdasarkan alat-alat bukti tertulis yang diajukan yang telah disahkan dalam persidangan Mahkamah, memenuhi syarat sebagai perorangan warga negara Indonesia dan oleh karena itu Pemohon mempunyai kapasitas untuk mengajukan permohonan pengujian undang-undang terhadap UUD 1945 sebagaimana dimaksud Pasal 51 ayat (1) hurufa UU MK.

Dalam pengajuan permohonan ini halhal pokok yang dijadikan alasan yaitu sebagai berikut:

1) Pemohon adalah perorangan warga negara Indonesia yang menganggap $\mathrm{hak} \mathrm{dan} / \mathrm{atau} \mathrm{kew}$ enangan konstitusionalnya telah dirugikan oleh berlakunya undang-undang, yaitu Undang-Undang Nomor 02/Pnps/1964 tentang Tata Cara Pelaksanaan Hukuman Mati, yang telah ditetapkan menjadi undangundang dengan Undang-Undang Nomor 5 Tahun 1969 tentang "Pernyataan Berbagai Penetapan Presiden dan Peraturan Presiden Sebagai Undang- Undang”.

2) Bahwa Pemohon dalam mengajukan permohonan ini bertindak dalam kapasitas atau kualifikasi pribadi sebagai warga negara Indonesia, sehingga dapat bertindak sendiri tanpa ijin maupun tanpa dapat dianggap mewakili kategori lain selain sebagai perorangan.

3) Bahwa sebagai warga negara Indonesia, maka Pemohon memiliki Hak Konstitusional yang diberikan oleh UUD 1945, yaitu Hak Untuk Tidak Disiksa, sebagaimana tersebut dalam

9. Ibid, hlm. 5-6. 
Pasal 28I ayat (1) perubahan kedua UUD 1945. Hak ini, selanjutnya menurut Pasal 28I ayat (1), merupakan hak asasi manusia yang tidak dapat dikurangi dalam keadaan apapun.

4) Bahwa Pemohon berpendapat hak konstitusional Pemohon untuk tidak disiksa telah dirugikan oleh berlakunya Undang-Undang tentang Tata Cara Pelaksanaan Hukuman Mati, karena Hukuman Mati dengan cara ditembak sampai mati menimbulkan kerugian yang bersifat khusus (spesifik) bagi Pemohon, yaitu berupa derita dan nestapa fisik yang sangat tidak diperlukan dalam proses kematian bagi Pemohon, dan kerugian ini menurut penalaran yang wajar dapat dipastikan akan terjadi, karena hukuman mati bagi Pemohon sudah memperoleh kekuatan hukum yang tetap (in kracht van gewijsde).

5) Bahwa kerugian berupa penyiksaan terhadap Pemohon adalah jelas hanya dapat terjadi sebagai akibat dari adanya penembakan oleh Regu Penembak, sedangkan kehadiran Regu Penembak untuk menembak Pemohon adalah sebagai akibat dari ketentuan undangundang yang dimohonkan oleh Pemohon untuk diuji. Dengan demikian terdapat hubungan sebab-akibat antara penyiksaan yang akan diderita oleh Pemohon dengan undang-undang yang dimohonkan untuk diuji.

6) Bahwa jika permohonan Pemohon ini dikabulkan maka sangat dimungkinkan bahwa kerugian berupa penyiksaan tidak lagi akan terjadi karena tata cara hukuman mati berupa penembakan dengan peluru tajam dapat digantikan dengan cara/metode lain yang lebih manusiawi. Bahwa menurut doktrin Hukum Islam yang merupakan the living law di Indonesia yang penduduknya mayoritas Muslim dan terbesar di dunia, disebutkan dalam mengeksekusi terpidana mati haruslah memenuhi syarat ihsan al-qathlu (eksekusi yang paling baik), yakni, melakukan eksekusi dengan cara yang paling baik, sehingga mempermudah kematian. Imam Muslim mengeluarkan riwayat dari Sadad bin Aus, bahwa Nabi Muhammad saw, bersabda: "Jika kalian mengeksekusi, maka mudahkanlah cara pembunuhannya. Dan jika kalian menyembelih, maka mudahkanlah penyembelihannya".

7) Bahwa Kitab Undang-Undang Hukum Pidana (KUHP), yang masih berlaku hingga sekarang telah mengatur tata cara hukum mati, sebagaimana dimaksud dalam Pasal 11 KUHP, yaitu "Pidana Mati dijalankan oleh algojo ditempat gantungan dengan menjeratkan tali yang terikat di tiang gantungan pada leher terpidana kemudian menjatuhkan papan tempat terpidana berdiri".

b. Keterangan Saksi dan Ahli Dari Pihak Pemohon

Untuk menguatkan dalil-dalilnya Pemohon mengajukan satu orang saksi dan beberapa orang ahli yang memberikan keterangan di persidangan. Adapun seorang saksi tersebut adalah seorang Rohaniawan yaitu Pastur Charlie Burrows. Pastur Charlie Burrows mengatakan berdasarkan pengalamannnya melihat pelaksanaan eksekusi pidana mati dengan cara tembak mati terhadap terpidana mati Antonius dan Samuel. Sesudah penembakan Antonius maupun Samuel mengerang kesakitan selama kurang lebih tujuh menit dan darah sudah mulai keluar dari jantungnya pelan-pelan dan agak lama, tetapi yang sangat menimbulkan rasa terharu adalah erangan kesakitan tersebut lama. Kemudian kurang lebih 10 menit setelah penembakan dokter memeriksa Samuel dan Antonius dan mengatakan bahwa mereka sudah meninggal dunia. Lebih lanjut Pastur Charlie Burrows mengatakan bahwa erangan selama 7 menit yang dialami oleh terpidana mati Antonius dan Samuel dirasakan seperti siksaan (cruel).

Beberapa ahli yang diajukan Pemohon adalah seorang Ahli Anastesi, seorang Ahli Bedah Orthopedi, seorang Ahli Hukum Islam, dan seorang Ahli Hukum Pidana. Tidak ketinggalan pula Pemohon juga mengajukan dua (2) orang Ahli lainnya dengan memberikan keterangan secara tertulis. Ahli Anastesi, dr. Sun Sunatrio mengatakan:

Bahwa eksekusi dengan cara penembakan berpotensi untuk 
menyiksa, sebab jarang dilakukan sehingga berpotensi untuk error, tidak tepat sasaran. Sehingga ahli mengusulkan dua pilihan cara pidana mati, yaitu pertama, injeksi dengan dosis obat anastetik dengan tiga macam obat dan dengan teknik yang benar; kedua, dengan cara dipancung, karena sangat singkat sekali. Mungkin tidak terasa oleh karena begitu cepatnya sehingga sampai dia pingsan tidak merasakan apa-apa. Dua pilihan tersebut menurut ahli, dianggap lebih ringan potensi menyiksanya. ${ }^{10}$

Ahli Bedah Orthopedi, dr. Jose Rizal Yurnalis, SpBO., dalam persidangan mengatakan:

Bahwa berdasarkan pengalaman ahli, kalau yang ditembak dengan peluru tajam, dia masih hidup kemudian pelanpelan meninggal, tentu dengan erangan kesakitan, jika tidak tepat dijantungnya, akan tetapi bila tepat dijantungnya maka jantung akan pecah dan langsung meninggal. Kalau nyerempet kemudian terkena vena cava atau arteri artha maka memerlukan waktu atau misalnya terkena paru-paru memerlukan waktu yang lebih lama lagi. Kadang-kadang memerlukan waktu $1 / 2$ jam, 1 jam, bahkan sampai 1 hari. Sedangkan kalau ditebas, ahli tidak melihat proses penebasannya, ahli hanya melihat hasilnya, dan menurut yang menyaksikan orang yang ditebas lehernya langsung meninggal. ${ }^{11}$

Ahli Hukum Islam, K.H. Mudzakir, berdasarkan keahliannya dalam persidangan mengatakan: ${ }^{12}$

Bahwa dalam syariat Islam, jika syariat sudah menetapkan hal tersebut boleh dilakukan maka boleh dilakukan, tetapi jika syariat menetapkan tidak boleh maka tidak boleh dilakukan; dengan demikian tidak sama hukum Indonesia dengan hukum Islam, misalnya ada seseorang melakukan perzinahan sementara dia sudah menikah maka dalam hukum Islam harus dihukum, sedangkan di luar hukum Islam harus ada salah satu yang menuntut terlebih dahulu baru dapat dituntut. Sehingga kalau ada seseorang melakukan perzinahan lalu dihukum dengan hukum Indonesia, maka dia belum terbebas menurut syariat Islam, oleh karena itu seseorang yang melakukan kejahatan di negeri Indonesia dan dihukum dengan undang-undang berdasarkan KUHP atau undang-undang lainnya yang berlaku, maka tidak membebaskan dia dari tanggung jawab di hadapan Allah SWT karena syariat Islam belum ditegakkan atas dirinya.

Lebih lanjut Ahli mengatakan bahwa tata cara pelaksanaan pidana mati dengan ditembak atau cara lainnya selain dengan dipancung masih terjadi rasa sakit yang luar biasa, disamping ada unsur menyiksa dan unsur merendahkan manusia, oleh karena itu menurut ahli, berdasarkan pilihan ulama sejak zaman dahulu yang memakai hukum pancung maka ahli tidak melihat sesuatu yang lebih baik dari pelaksanaan hukuman mati kecuali dengan dipancung wallahu'alam.

Ahli Hukum Pidana, Dr. Rudi Satrio, SH., MH., dalam persidangan mengatakan:

Bahwa terkait dengan persoalan pelaksanaan pidana mati maka menurut ahli adalah harus yang terbaik untuk terpidana, tidak menyiksa dan mempercepat proses kematian, maka didasarkan pada masalah perkembangan pengetahuan dan teknologi manusia memungkinkan dipertimbangkan diambil jalan yang terbaik agar kematian tersebut tidak menyiksa dan kemudian lebih cepat dapat dilaksanakan. Hal tersebut merupakan suatu permintaan dari undang-undang agar setiap saat tidak menutup kemungkinan adanya perubahan-perubahan tentang masalah bagaimana tata cara melaksanakan eksekusi. ${ }^{13}$

Dua Ahli lainnya yang diajukan Pemohon memberikan keterangan secara tertulis, Ahli Dr. Salman Luthan, S.H., M.H.,

10. Putusan MK No. 21/PUU-VI/2008, hlm. 18.

11. Ibid, hlm. 18-19.

12. Ibid, hlm. 23-24.

13. Ibid, hlm. 26. 
mengatakan:

Pelaksanaan pidana mati dengan cara ditembak mati dipilih karena dianggap lebih praktis dan memiliki efek psikologis yang lebih ringan bagi eksekutor pidana mati karena menembak mati dilakukan secara bersama-sama oleh 1 regu tembak. Dengan kata lain, pelaksanaan pidana mati dengan cara menembak mati lebih berorientasi kepada kepentingan eksekutor hukuman mati daripada kepentingan terpidana mati. ${ }^{14}$

Sedangkan satu lagi Ahli, Ahli Muhammad Luthfie Hakim, S.H., M.H., secara tertulis memberikan keterangan:

Mengenai hukuman mati dengan cara dipenggal kepala merupakan pilihan baik untuk diterapkan di Indonesia, menurut ahli, apabila alat untuk memenggal (biasanya berupa pedang atau kampak) benar-benar tajam (sharp) dan teknik memukul yang dilakukan oleh algojo (executioner) tepat pada sasaran, maka cara hukuman mati dengan memenggal leher ini dikenal yang paling sedikit menimbulkan rasa sakit (painlessness) bagi terpidana. ${ }^{15}$

Berdasarkan penjelasan di atas, maka dapat ditarik kesimpulan bahwa semua keterangan Saksi dan Ahli yang diajukan oleh Pemohon menyatakan tidak setuju dengan cara tembak mati sebagai eksekusi terhadap terpidana mati. Adapun yang dijadikan alasan mayoritas ahli karena adanya kemungkinan sebelum terpidana mati setelah di eksekusi dengan cara tembak mati adanya kemungkinan mengalami penderitaan yang menyakitkan. Terlebih jika tembakan eksekutor meleset dikarenakan tidak tepat mengenai jantung terpidana mati, jika tembakan tersebut mengenai vena cava atau arteri artha maka memerlukan waktu atau misalnya terkena paru-paru memerlukan waktu yang lebih lama lagi. Kadang-kadang memerlukan waktu $1 / 2$ jam, 1 jam, bahkan sampai 1 hari. Sedangkan kalau eksekusinya dilakukan dengan cara ditebas lehernya langsung meninggal. c. Penjelasan Pemerintah Mengenai Tata

Cara Pelaksanaan Pidana Mati

Pihak Terkait memberikan keterangan, dalam hal ini Pemerintah memberikan keterangan dalam persidangan yang diwakili oleh Menteri Hukum dan Hak Asasi Manusia, menyimpulkan bahwa pengertian sakit atau rasa sakit bagi terpidana mati yang sedang menjalani eksekusi pidana mati tidak termasuk kategori penyiksaan atau penganiayaan, karena pada hakikatnya pelaksanaan eksekusi pidana mati tidak dimaksudkan untuk menimbulkan rasa sakit, tetapi sebagai konsekuensi logis dari proses kematian atas putusan pengadilan yang telah mempunyai kekuatan hukum mengikat (inkracht van gewijsde). Sehingga menurut Pemerintah, Undang-Undang Nomor 2/Pnps/1964 tentang Tata Cara Pelaksanaan Hukuman Mati yang dijatuhkan oleh Pengadilan di Lingkungan Peradilan Umum dan Militer, baik secara formiil maupun matriil tidak bertentangan dengan ketentuan Pasal 28I ayat (1) Undang-Undang Dasar Negara Republik Indonesia Tahun 1945, dan karenanya tidak merugikan hak dan/atau kewenangan konstitusional Pemohon. ${ }^{16}$

d. Dasar Pertimbangan MK dalam Memutus Uji Konstitusionalitas Tembak Mati Sebagai Eksekusi Pidana Mati

Dalam Rapat Permusyawaratan Hakim yang dihadiri oleh sembilan Hakim Konstitusi, pada hari Rabu, tanggal lima belas bulan Oktober tahun dua ribu delapan, dan diucapkan dalam Sidang Pleno Mahkamah Konstitusi terbuka untuk umum pada hari ini, Selasa tanggal dua puluh satu bulan Oktober tahun dua ribu delapan, oleh kami, Moh. Mahfud, MD selaku Ketua merangkap Anggota, Maruarar Siahaan, H.M. Arsyad Sanusi, Muhammad Alim, H. Abdul Mukthie Fadjar, Jimly Asshiddiqie, Maria Farida Indrati, H.M. Akil Mochtar, dan Achmad Sodiki, masing-masing sebagai Anggota dengan didampingi oleh Cholidin Nasir sebagai Panitera Pengganti, serta dihadiri oleh Pemohon/Kuasanya, Pemerintah atau yang mewakili, dan Dewan Perwakilan Rakyat atau yang mewakili. Pada akhirnya 
Mahkamah menyatakan "permohonan Pemohon baik mengenai pengujian formil maupun pengujian materiil ditolak untuk seluruhnya". Adapun yang dijadikan yang dijadikan dasar pertimbangan oleh Mahkamah pada intinya sebagai berikut: ${ }^{17}$

UU 2/Pnps/1964 yang menentukan pelaksanaan pidana mati dengan cara ditembak, memang menimbulkan rasa sakit yang melekat di dalam pelaksanaan pidana mati sebagai akibat putusan hakim yang sah. Meskipun terdapat tata cara lain dalam pelaksanaan pidana mati sebagaimana dikemukakan para ahli yang dapat menimbulkan kematian lebih cepat dan tidak menimbulkan rasa sakit yang berkepanjangan, tetapi hal tersebut tidak berkaitan dengan konstitusionalitas undang-undang yang diuji, karena dengan cara apapun bila tidak dilakukan dengan tepat, akan menimbulkan rasa sakit, yang mengesankan sebagai penyiksaan. Lagipula, sepanjang yang berhubungan dengan tembakan pengakhir karena kegagalan tembakan pertama tidak terdapat data-data yang membuktikan terjadinya kegagalan tersebut, sehingga Mahkamah harus mengesampingkan. Namun demikian, perkembangan ilmu pengetahuan dan teknologi seyogianya dimanfaatkan dalam pencarian cara-cara pelaksanaan pidana mati yang lebih manusiawi, cepat, dan tidak menimbulkan rasa sakit yang lama. Hal tersebut merupakan tugas pembentuk undang-undang untuk melakukan pengkajian atas kemungkinan mengubah UU 2/Pnps/1964 agar lebih sesuai dengan perkembangan ilmu pengetahuan dan teknologi.

Senada dengan pandangan Mahkamah Konstitusi, Hwian Cristianto ${ }^{18}$ berpendapat bahwa pada setiap eksekusi pidana mati rasa sakit yang dirasakan oleh terpidana tidak bisa dihindarkan. Meskipun demikian tidak berarti dibenarkan memilih model apapun untuk melakukan pelaksanaan pidana mati.
Pelaksanaan pidana mati haruslah memperhatikan tujuan dari dilakukannya eksekusi (untuk matinya terpidana) bukan untuk menyiksanya. Cara pelaksanaan juga tidak diperbolehkan terlalu sadis karena bisa mengakibatkan terganggunya rasa keadilan masyarakat yang berdiri di atas nilai-nilai kemanusiaan yang beradab.

\section{Simpulan}

Argumentasi Pemohon dan dasar pertimbangan dalam Putusan MK No. 21/PUU-VI/2008 setidaknya terpenuhi. Dalam hal ini, Pemohon mengajukan Saksi beserta berbagai Ahli berdasarkan pengalaman dan keahliannya masing-masing. Ada Rohaniawan, Ahli Anastesi, Ahli Bedah Orthopedi, Ahli Hukum Islam, dan Ahli Hukum Pidana. Tidak ketinggalan pula dari pihak Pemerintah juga memberikan keterangan dalam persidangan, dimana keterangan-keterangan tersebut sebagian digunakan sebagai dasar pertimbangan untuk mengambil keputusan oleh Mahkamah. Namun, putusan Mahkamah bisa juga ditafsirkan bahwa eksekusi terhadap terpidana mati dapat saja tidak dengan cara tembak mati agar lebih sesuai dengan perkembangan ilmu pengetahuan dan teknologi. Berdasarkan hal ini, maka tugas pembentuk undang-undang untuk melakukan pengkajian.

\section{Daftar Pustaka}

Adji Samekto FX., 2012, “Menggugat Relasi Filsafat Posistivisme Dengan Ajaran Hukum Doktrinal", Jurnal Dinamika Hukum, Vol. 12, No. 1, Januari, hlm. 74 -84 .

Cristianto Hwian, 2009, "Tata Cara Pelaksanaan Pidana Mati bagi Terpidana Mati dalam Hukum Pidana", Jurnal Konstitusi, Vol. 6, No. 1, April, hlm. 25-38.

Gazalba Sidi, 1992, Sistematika Filsafat: Buku Pertama: Pengantar Kepada Dunia Filsafat, Jakarta, PT Bulan Bintang.

\footnotetext{
17. Ibid, hlm. 74 .

18. Hwian Cristianto, "Tata Cara Pelaksanaan Pidana Mati bagi Terpidana Mati dalam Hukum Pidana”, Jurnal Konstitusi, Vol. 6, No. 1, April 2009, hlm. 38.
} 
Mahkamah Konstitusi, 2004, Cetak Biru Membangun Mahkamah Konstitusi, Jakarta, Mahkamah Konstitusi Republik Indonesia.

S Suriasumantri Jujun, 2007, Filsafat Ilmu: Sebuah Pengantar Populer, Jakarta, Pustaka Sinar Harapan

Suastuti Eny, 2007, Pendekatan Filsafat Ilmu Dalam Ilmu Hukum, Bunga Rampai Hakikat Keilmuwan Ilmu Hukum: Suatu Tinjauan dari Susut Pandang Filsafat Ilmu, penyunting. Trianto \& Titik Triwulan Tutik, Jakarta, Prestasi Pustaka.

Kitab Undang-Undang Hukum Pidana.

Undang-Undang Dasar Negara Republik Indonesia 1945.

Undang-Undang Nomor 2/PNPS/1964 Tahun 1964 tentang Tata Cara Pelaksanaan Pidana Mati yang Dijatuhkan Oleh Pengadilan di Lingkungan Peradilan Umum dan Militer.

Putusan Mahkamah Konstitusi Nomor 21/PUU-VI/2008. 